\title{
Influence of European Quail Breeders Age on Egg Quality, Incubation, Fertility and Progeny Performance
}

http://dx.doi.org/10.1590/1516-635x170149-56

\section{mauthor(s) \\ Santos TC' \\ Murakami $A E^{\prime}$ \\ Oliveira CAL' \\ Moraes GV \\ Stefanello C" \\ Carneiro TV"I \\ Feitosa CCG" \\ Kaneko IN"}

Department of Animal Science, State University of Maringá, Av. Colombo 5790, Maringá, PR 87020-900, Paraná, Brazil.

" Students of Post-graduation Program in Animal Science, University of Maringá, PR, Brazil.

III Students of Graduation in Animal Science, University of Maringá, PR, Brazil.

\section{Mail Address}

Corresponding author e-mail address Santos TC

Department of Animal Science, State University of Maringá, Av. Colombo 5790, Maringá, CEP 87.020-900, Paraná, Brazil. Phone: (5544) 30118943 or (5544) 3011 4919

E-mail: tcsantos@uem.br

\section{nKeywords}

Breeders, Egg quality, Hatching, Sperm-egg, Perivitelline Tayer, Quail.

\section{ABSTRACT}

The influence of age (85, 140, and 270 days) of European quails breeders on the egg quality and hatching, fertility and progeny performance was evaluated. The experimental design was completely randomized in a $3 \times 3$ factorial arrangement (females' age $x$ males' age), with ten replicates and six birds per experimental unit (four females and two males). Egg production and quality were determined during 3 periods of 14 days and incubation parameters were evaluated in eggs obtained in five consecutive days. The live performance of the progenies was analyzed until 35 days. There was no effect of male age or any interaction between the age of males and females for the evaluated variable. The female's age influenced egg production, egg weight and chick weight, with better results obtained for 140-d-old breeders. The age of females reduced the hatchability, increased the late mortality in incubated eggs, and had no effect on fertility, total embryo mortality or eggshell structure, when analyzed by electron microscopy. The number of sperm trapped in the outer perivitelline layer $\left(\mathrm{sptz} / \mathrm{mm}^{2}\right)$ was determined in 10 fertile eggs per experimental unit. Young females fertilized by young males ( 80 days) had reduced sptz $/ \mathrm{mm}^{2}$. Progeny live performance was not affected by breeder's age. Breeders with 270 days retain fertility; however, their egg production, weight and hatchability of fertilized eggs is reduced. In conclusion, European quail breeders with 140 days of age have better egg quality, hatching and breeding results.

\section{INTRODUCTION}

Brazilian quail production is predominantly focused on eggs. There is an increasing interest on meat production, but production is still small and should increase slowly due to lack of habit of consuming this type of meat (Costa et al., 2008). Little is known about the productive potential of quails in Brazil and production costs, making its meat price high and uncompetitive in the retail market compared with chicken meat (Móri et al., 2005a). The lack of suitable genetic material and insufficient data on the performance and nutritional requirements make meat quail production poorly organized and empirical (Móri et al., 2005a).

European quail (Coturnix coturnix coturnix) and American quail (Colinus virginianus) are commercial species used for meat production (Murakami \& Ariki, 1998). The rearing of quails for meat production is a good way to obtain animal protein as it is an activity with great potential for expansion because it demands little space and labor, and low investment.

Several factors affect the performance of commercial poultry, such as genetics, nutrition, health, rearing environment, management, breeder's age and egg weight at incubation (Corrêa et al., 2011; Ayasan, 2013a). 
In broiler breeders, age has a direct influence on egg quality, composition and size, because egg production is reduced, egg (yolk and albumen) changes and egg weight increases as hens age (Rocha et al., 2008).

The fertility of poultry depends on success of a number of critical steps of spermatogenesis, extragonadal maturation, and survival and function of sperm in the oviduct (Froman et al., 2004). In quails, male reproductive strategies involve the rapid production, maturation and transport of sperm through the reproductive tract associated with a limited capacity for stock in genital ducts (Clulow \& Jones, 1982).

The present study aimed at evaluating the influence of the age of quail breeders, by promoting mating of breeders at different reproductive stages, on egg quality, fertility, and hatchability, and on the live performance of their progeny. for four consecutive days, the egg weight, specific gravity, and eggshell percentage and thickness were determined. All intact eggs of each experimental unit have weighed and tested for specific gravity in saline densities ranging from 1.066 to $1.082 \mathrm{~g} / \mathrm{mL}$. The Haugh unit was determined in three eggs/experimental unit, according to the formula: $\mathrm{UH}=100 \log (H+7.57-$ $\left.1.7 \mathrm{~W}^{0.37}\right)$, where: $\mathrm{H}=$ albumen height $(\mathrm{mm}), \mathrm{W}=$ egg weight (grams) (Haugh, 1937). The shells were washed and dried to determine their percentage and thickness with the aid of digital caliper.

To analyze the eggshell structure, shells of 05 eggs of each breeder age were randomly selected and analyzed. Shells were washed and dried and fragments from the equatorial region were glued on stubs, metalized for 15 min and analyzed by scanning electron microscope (SEM) (Shimadzu SS-550 Superscan). Cross-

\section{MATERIAL AND METHODS}

The experiment was conducted at the Experimental Farm of the State University of Maringá (UEM), Brazil. Quail breeders were housed in galvanized wire cages with nipple drinkers and trough feeders disposed in front of the cages. Birds were given feed and water ad libitum, and 17 hours lighting schedule. Breeder groups were formed by four females and two males per experimental unit and the observations made at 85 (young), 140 (adult) and 270 (old) days of age.

Quail breeders were distributed into a completely randomized design with a $3 \times 3$ factorial arrangement (females and males age) with ten replicates and six birds per experimental unit. For the evaluation of the live performance of the progeny from quail breeders, birds were distributed into an experimental design with a $3 \times 3$ factorial arrangement (females and males age) with four replicates and 30 birds per experimental unit. Diets were formulated according to nutritional requirements and feed composition (Rostagno et al., 2005). The ingredients and the calculated composition of the diets used for breeders and offspring of quails are in Table 1.

In breeders, the egg production and quality were determined in three 14-day cycles. At the end of each 14-day interval,
Table 1 - Ingredient composition and calculated nutritional values of the experimental diets fed during lay to quail breeders and during the rearing phase to chicks ( 1 to 14 and 15 to 35 days).

\begin{tabular}{|c|c|c|c|}
\hline \multirow[t]{2}{*}{ Ingredients (\%) } & \multirow{2}{*}{$\begin{array}{c}\text { Breeders } \\
\text { Laying }\end{array}$} & \multicolumn{2}{|c|}{ Chicks } \\
\hline & & 1 to 14 days & 15 to 35 days \\
\hline Corn & 56.97 & 60.02 & 65.01 \\
\hline Soybean meal (45\% CP) & 32.64 & 36.49 & 31.90 \\
\hline Dicalcium phosphate & 1.31 & 0.79 & 0.81 \\
\hline Limestone & 5.87 & 1.05 & 1.06 \\
\hline Soybean Oil & 2.20 & 0.22 & 0.27 \\
\hline Salt & 0.35 & 0.40 & 0.35 \\
\hline DL-methionine (98\%) & 0.20 & 0.28 & 0.13 \\
\hline L-lysine $\mathrm{HCl}(78 \%)$ & 0.14 & 0.18 & 0.00 \\
\hline L-threonine (98\%) & 0.00 & 0.22 & 0.07 \\
\hline Vitamin and mineral premix1,2 & 0.321 & 0.352 & 0.402 \\
\hline \multicolumn{4}{|l|}{ Calculated nutritional values } \\
\hline Metabolized energy (kcal/kg) & 2,900 & 2,900 & 2,950 \\
\hline Crude protein (\%) & 20.00 & 22.00 & 19.95 \\
\hline Calcium (\%) & 2.70 & 0.80 & 0.80 \\
\hline Available phosphorus (\%) & 0.35 & 0.30 & 0.30 \\
\hline Digestible lysine (\%) & 1.05 & 1.20 & 0.95 \\
\hline Digestible methionine + cystine (\%) & 0.75 & 0.88 & 0.69 \\
\hline
\end{tabular}

Mineral and vitamin supplement - Nucleopar Animal Nutrition Ltda. (Content per kg of diet):

'Vit. A 4,500,000 IU; Vit. D3 1,250,000 IU; Vit. E 4,000 mg; Vit. B1 278 mg; Vit. B2 2,000 mg; Vit. B6 525 mg; Vit. B12 5,000 cg; Vit. K3 1.007 mg; Calcium Pantothenate 4,000 mg; Niacin 10,000 mg; Choline 140,000 mg; Antioxidant 5,000 mg; Zinc 31,500 mg; Iron 24,500 mg; Manganese 38,750 mg; Copper 7,656 mg; Cobalt 100 mg; lodine 484 mg; Selenium $127 \mathrm{mg}$

${ }^{2}$ Vit. A 2, 550 IU/g; Vit E 2,083.33 mg; Vit D3 500 IU/g; Vit K3 650 mg; Vit B1 408.33 mg; Vit B12 2,500 mg; Vit B2 1,000 mg; Vit B6 412.5 mg; Folic Ac. 66.67 mg; Biotin 8.33 mg; Choline 70,000 mg; Pantothenic Ac. 2,375 mg; Methionine 226,875 mg; Niacin 5,308.33 mg; Iron 12,500 mg; lodine 258.33 mg; Selenium 75 mg; Cobalt 83.33 mg; Antioxidant 1,250 mg. 
section fragments of the eggshell were measured in 20 different points to determine the thickness $(\mu \mathrm{m})$ of crystal+palisade layer, mammillary layer, cuticular layer, total eggshell, and inner membrane fibers. The percentage of each layer was calculated in the ratio of the total thickness and the percentage of membrane fiber determined based on formula: macroscopic eggshell thickness - membrane thickness determined by SEM.

The sperm-egg interaction was analyzed in 10 fertile eggs per experimental unit. Eggs were stored at $5^{\circ} \mathrm{C}$, broken up and fertility analysis performed by the blastoderm morphology (Kosin, 1945). Fragments of $1.5 \mathrm{~mm}^{2}$ perivitelline membrane on the germinal disc were cut off and washed with $1 \% \mathrm{NaCl}$ solution to remove the yolk. These fragments were placed on a histological slide and treated with $5 \mu \mathrm{L}$ DAPI (4',6-diamidino-2-phenylindole, dihydrochloride solution at $5 \mu \mathrm{mol})$ to identify the nucleus of sperm by labeling their DNA (Wishart, 1997). Fragments were covered by a coverslip, and analyzed with a fluorescence microscope (Fig. 1). Each membrane was analyzed in 5 microscope fields under a 20x objective lens and sperm counted in an area of $3.75 \mathrm{~mm}^{2}$. Data are expressed in sperm $/ \mathrm{mm}^{2}$.

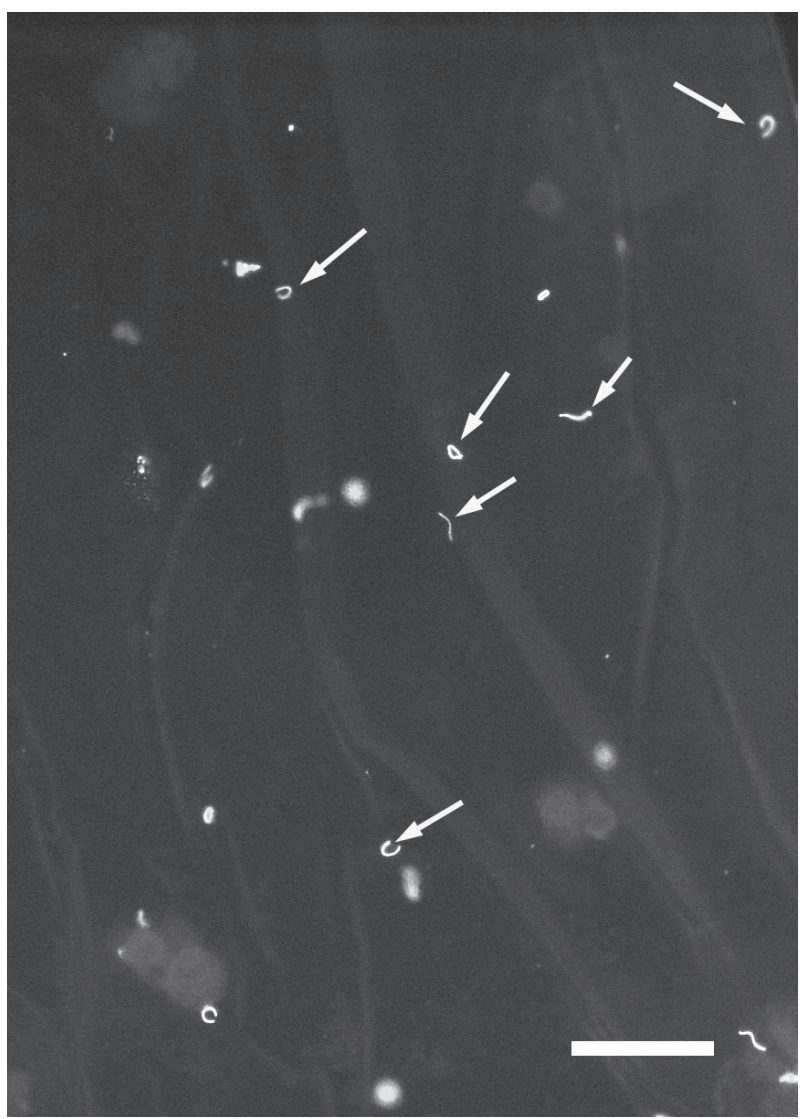

Figure 1 - Perivitelline membrane evidencing sperm nuclei (arrow) labeled with DAPI and observed under fluorescence microscope. Bar $=50 \mu \mathrm{m}$.
In order to evaluate the influence of breeder age on egg hatchability, we collected eggs in two periods of five consecutive days, which were stored in cooled room at $18-20^{\circ} \mathrm{C}$. Eggs were identified per experimental unit and incubated in automatic incubator with control of humidity $(60 \%)$ and temperature $\left(37.6^{\circ} \mathrm{C}\right)$. On the $15^{\text {th }}$ day, eggs were transferred to a hatching chamber and after two days the hatched chicks with down dried were weighed and transferred to the rearing area. Unhatched eggs were opened to determine fertility, hatchability (based on fertilized eggs), and mortality (early, intermediate, and late embryonic mortality, and pipped eggs) rates.

One-day chicks were divided into 36 pens $\left(2.5 \mathrm{~m}^{2}\right)$ of 30 birds (4 experimental units/treatment), according to the experimental design used in the hatchery. Quails were housed in a shed with a rice straw litter with infrared heating lamps up to 14 days and 24 hours continuous light during the experimental period, receiving water and food ad libitum. The progeny performance was evaluated until 35 days to determine the average weight, weight gain, feed intake and feed conversion. Birds were fed two diets: starter (1-14 days) and grower (15-35 days) (Table 1).

\section{Statistical analysis}

Data of egg quality, eggshell structure, chick weight and embryonic mortality were subjected to analysis of variance and Tukey's test, when significant at 5\% probability. To evaluate the number of sptz/$/ \mathrm{mm}^{2}$ of the perivitelline layer we used the methodology of general linear models, considering the Gamma distribution and the inverse link function, implemented in PROC GEN MOD of SAS (2000). The following orthogonal contrasts were evaluated: female and male of 85 days vs. female of 85 and male of 140 days; female and male of 85 days vs. female of 85 and male of 270 days; female of 85 days $v$ s. female of 140 days; female of 85 days vs. female of 270 days; female of 140 and male of 85 days vs. female and male of 140 days; female of 140 and male of 85 days vs. female of 140 and male of 270 days; female 270 and male of 85 days vs. female of 270 and male of 140 days; female of 270 and male of 85 days vs. female of 270 and male of 270 days.

\section{RESULTS AND DISCUSSION}

Egg quality and incubation performance results are listed in Table 2 . The age of male had no effect $(p>0.05)$ or interaction between age of breeders on analyzed variables. However, the age of females influenced the egg production, weight, Haugh unit, 
Table 2 - Egg quality and analysis of incubation according to the age of quail breeders (85, 140, and 270 days).

\begin{tabular}{|c|c|c|c|c|c|c|c|c|c|c|}
\hline & \multicolumn{3}{|c|}{ Female (Fe) } & \multicolumn{3}{|c|}{ Male (Ma) } & \multirow[b]{2}{*}{ CV\% } & \multicolumn{3}{|c|}{ ANOVA } \\
\hline & 85 & 140 & 270 & 85 & 140 & 270 & & $\mathrm{Fe}$ & Ma & Fe $\times \mathrm{Ma}$ \\
\hline \multicolumn{11}{|l|}{ Egg quality } \\
\hline Egg production (\%) & $77.93^{b}$ & $91.94^{\mathrm{a}}$ & $81.86^{b}$ & 82.72 & 83.39 & 86.42 & 11.12 & $<0.0001^{*}$ & ns & ns \\
\hline Egg weight (g) & $12.73^{b}$ & $13.43^{\mathrm{a}}$ & $12.56^{b}$ & 12.46 & 13.15 & 13.10 & 6.63 & 0.0001 & ns & ns \\
\hline Specific weight & 1.0712 & 1.0706 & 1.0711 & 1.0709 & 1.0708 & 1.0777 & 0.10 & ns & ns & ns \\
\hline Haugh unit & $91.90^{\mathrm{a}}$ & $90.81^{b}$ & $90.61^{b}$ & 91.28 & 91.12 & 90.91 & 1.22 & $<0.0001$ & ns & ns \\
\hline Eggshell (\%) & $7.73^{\mathrm{ab}}$ & $7.54^{b}$ & $7.81^{\mathrm{a}}$ & 7.86 & 7.63 & 0.58 & 5.54 & 0.041 & ns & ns \\
\hline Eggshell thickness (mm) & 0.221 & 0.221 & 0.216 & 0.220 & 0.220 & 0.220 & 3.83 & ns & ns & ns \\
\hline \multicolumn{11}{|l|}{ Incubation } \\
\hline Weight at hatch (g) & $8.99^{b}$ & $9.85^{a}$ & $9.04^{b}$ & 9.26 & 9.32 & 9.29 & 6.46 & $<0.0001$ & ns & ns \\
\hline Fertility (\%) & 95.47 & 94.24 & 92.87 & 94.85 & 94.09 & 93.65 & 7.84 & ns & ns & ns \\
\hline Hatchability (\%) & $92.28^{a}$ & $91.02^{\mathrm{ab}}$ & $85.52^{b}$ & 90.73 & 85.54 & 92.55 & 11.54 & 0.009 & ns & ns \\
\hline Total mortality (\%) & 7.17 & 8.31 & 13.36 & 8.72 & 13.30 & 6.83 & 97.91 & & & \\
\hline Early (\%) & 1.86 & 2.01 & 3.19 & 2.28 & 2.7 & 2.07 & - & ns & ns & ns \\
\hline Intermediary (\%) & 0.50 & 0.80 & 1.69 & 0.58 & 1.81 & 0.6 & - & ns & ns & ns \\
\hline Late (\%) & $1.75^{\mathrm{b}}$ & $3.12^{\mathrm{ab}}$ & $4.53^{\mathrm{a}}$ & 2.84 & 4.27 & 2.29 & - & 0.040 & ns & ns \\
\hline Piped egg (\%) & 3.07 & 2.37 & 3.96 & 3.08 & 4.52 & 1.86 & - & ns & ns & ns \\
\hline
\end{tabular}

${ }^{a-b}$ means of the same variable followed by different letters in the row differ significantly for the treatments by Tukey test $(p<0.05) ;{ }^{*} p$ value; ns: not significant ( $\left.p>0.05\right)$.

eggshell percentage and weight of chicks at hatch. The egg production and egg weight were higher $(p<0.05)$ for 140 -d-old breeders. The highest Haugh unit was observed in the eggs from young quails (85 days), according to egg weight, which was influenced by age.

Móri et al. (2005b) used four strains of quails and analyzed egg production, egg weight and average feed intake. The authors found no differences ( $p>0.05$ ) among the groups within 42 to 210 days of age for the average feed intake and egg production, and the values for egg production ranged from 80 to $84.49 \%$ in this period.

The results of egg weight and Haugh unit are in agreement with Nowaczewski et al. (2010), who described the increase in egg size with age in Japanese quail. These authors studied these animals up to 217 days and mentioned that the albumin became denser and proportionally smaller, resulting in a decrease of the height thereof.

The breeder age influenced $(p<0.05)$ the eggshell percentage in the studied birds, with old females producing eggs with greater eggshell percentage; however, these females also presented a reduced egg weight, thereby increasing eggshell percentage. There was no effect ( $p>0.05$ ) of age of quail breeders on the shell thickness and egg specific weight. When analyzed under scanning electron microscopy, the shell thickness also remained without any differences between the studied ages, and it can be said that up to 270 days old of quails, eggshells did not vary in total thickness $(0.174 \mathrm{~mm})$ or in the proportion between the different layers that make up the eggshell $(21.49 \%$ for mammillary layer, $75.54 \%$ for palisade+crystal layer and $5.19 \%$ for shell cuticle) (Table 3, fig. 2). The macroscopic thickness $(0.219 \mathrm{~mm})$ includes the fibrous membrane of the eggshell, which was determined in SEM as having an average thickness of $36 \mu \mathrm{m}$ or $0.036 \mathrm{~mm}$, representing about $16.4 \%$ of the thickness usually observed macroscopically. This proportion is much higher than that observed in broiler eggs, since the weight of the eggs produced by $270-d$-old breeders decreased, but the specific gravity, eggshell thickness and Haugh unit were maintained and were similar to those produced by 140 -d-old breeders.

The influence of female age is well described in laying hens, in which the egg size changes considerably, increasing egg size and weight and reducing the shell 
Table 3 - Data from eggshell structural layers analyzed by SEM according to the age of quail breeders (85, 140, and 270 days).

\begin{tabular}{|c|c|c|c|c|c|}
\hline & & reeders age (days) & & & \\
\hline Thickness $(\mu \mathrm{m})$ & 80 & 140 & 270 & CV\% & Effect \\
\hline Total* & 170.86 & 165.01 & 185.69 & 11.25 & ns \\
\hline Mammillary & $34.56(20.57 \%)$ & $32.27(75.03 \%)$ & $35.39(4.4 \%)$ & 5.46 & ns \\
\hline Palisade + crystal & $126.2(21.60 \%)$ & $109.78(72.54 \%)$ & $116.17(5.85 \%)$ & 9.38 & ns \\
\hline Cuticle & $7.33(22.24 \%)$ & $8.52(72.43 \%)$ & $8.48(5.32 \%)$ & 10.47 & ns \\
\hline Eggshell membrane & 35.69 & 38.58 & 35.83 & 6.98 & ns \\
\hline
\end{tabular}

"Eggshell thickness without eggshell membrane; ns: not significant ( $p>0.05)$.

thickness and Haugh unit value (Akyurek \& Okur, 2009; Roll et al., 2009), reflecting the overall quality of the eggshell. Apparently, the same effect does not occur with quail breeders.

Regarding the analysis of egg incubation, 140-d-old quail breeders produced the heaviest chicks at hatch $(p<0.05)$, indicating that the age of the females interfered with this parameter. There was no effect $(p>0.05)$ of breeder age on fertility and infertility (Table 2).

A positive relationship between egg weight and chick weight at hatch was observed in this study. Quail

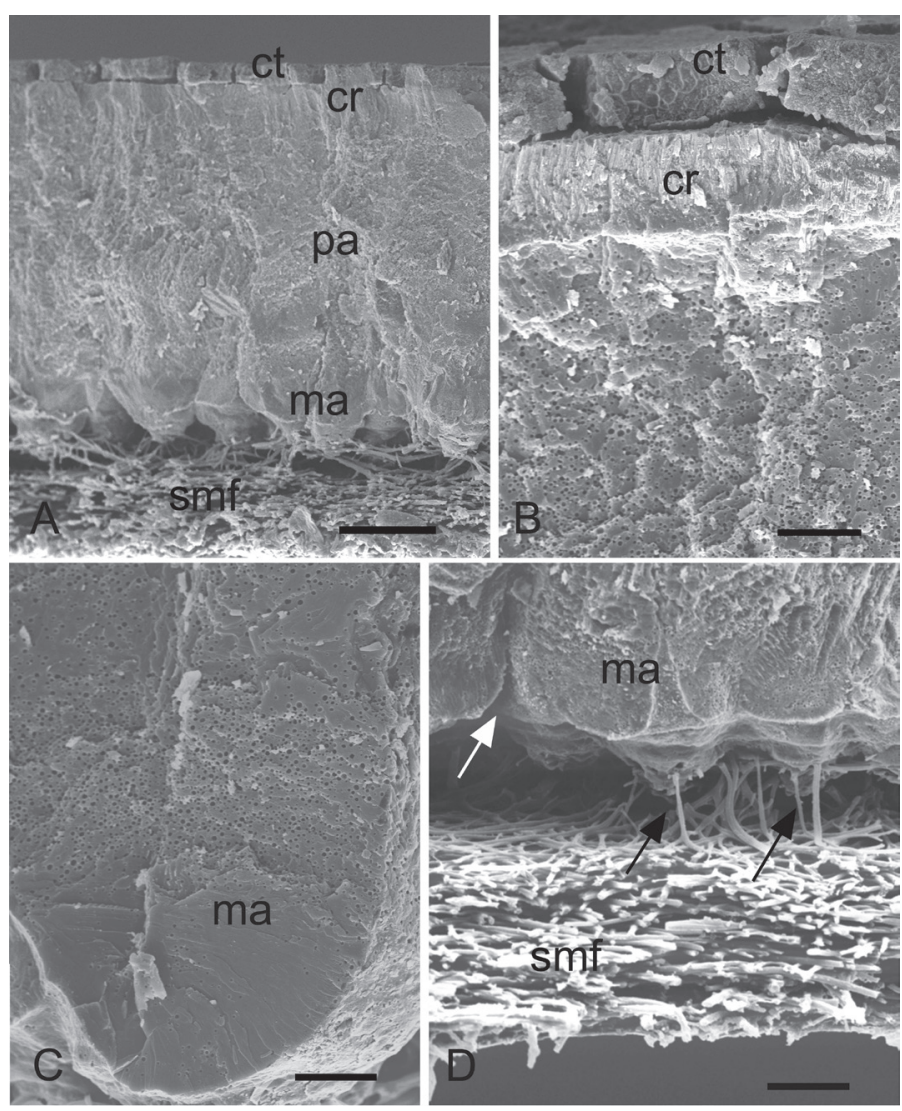

Figure 2 - A-D) Eggshell cross section of the European quail egg (80 days) visualized by scanning electron microscopy. Eggshell layers are evident: cuticular (ct), crystal (cr), palisade (pa), and mammillary (ma), and the shell membrane fibers (smf). D) Detail of the fibers connecting the shell membrane with the mammillary layer (black arrow) and a gas exchange pore (white arrow). Scale bar: A) $50 \mu \mathrm{m}, \mathrm{B}-\mathrm{C}) 10 \mu \mathrm{m}$, and D) $20 \mu \mathrm{m}$. breeders at 140 days of age produced eggs with higher average weight $(p<0.05)$ and, consequently, heavier chicks at hatch. The results for chick weight at hatch are in accordance with those found by Corrêa et al. (2011). These authors also observed that chicken quails originated from older breeders (270 days of age) presented lower $(p<0.05)$ hatch weight. As reported by Roque \& Soares (1994) and Santos et al. (2009), this can be explained by the transformation that occurs in the shell, cuticle and membrane of the egg with advancing age of the breeder that, in this case, may have influenced water loss during incubation, leading to lighter quails at hatch, when originated from older hens.

The egg weight influences the chick weight at hatch. The weight of one-d-old chicks can influence their performance at slaughter, given the associations between egg weight and chick weight, and chick weight and slaughter weight (Wilson, 1991). The practice of classifying the eggs in the hatchery as a function of egg weight and breeder age of the breeder is due to the positive correlation between egg weight and chick weight. With this, it is possible to produce more uniform quail chick flocks that are easier to manage during the rearing period (Corrêa et al., 2011).

The fertility of quail breeders showed no change throughout reproductive life, and was $94.20 \%$, on average. These values are close to those observed by Santos et al. (2011), who obtained an average fertility of $98.15 \%$ in $120-d$-old quail breeders. Hassan et al. (2003) evaluated quails with approximately 310 days of age and found a fertility value of $72.10 \%$, lower than found herein, even in the treatments with higher age (270 days). Dere et al. (2009) reported no fertility differences in eggs from breeders with 90 and 180 days, with values of $82.01 \%$ and $81.7 \%$, respectively. The hatchability results found in the present study in eggs laid by 85 - and 140-d-old breeders are consistent with those reported by Seker et al. (2004) in quails at 70 and 140 days, of $87.64 \%$ hatchability in fertile eggs. The same authors cited no difference in the fertility 
rate $(78.86 \%)$ between ages analyzed, when male to female ratio was 1:2. Ayasan (2013b) obtained lower results in the eggs from 8-week-old quails, where fertility rate was $85.09 \%$ and hatchability of fertile eggs was $78.45 \%$ in control groups.

Albino \& Barreto (2003) recommend replacing old males after 5 months by younger ones. In the present study, breeding old females (210 days) with younger males did not improve fertility and hatchability. In the treatments with young females ( 85 days) and old males (140 or 270) no differences were observed in fertility and hatchability, and only female age influenced these parameters (Table 2).

The results of the number of sperm analyzed in fertile eggs are listed in Table 4. Eggs from quail breeders showed $9.35 \mathrm{sptz} / \mathrm{mm}^{2}$ on average. According to the analysis of contrasts of the number sptz $/ \mathrm{mm}^{2}$ of fertile eggs, the eggs of the breeding groups formed by females and young males ( 85 days), and of those with young females and older males (140 to 270 days) presented higher number of sperm $(p<0.05)$. Apparently, younger breeders presented a higher number of sperm in the infundibulum at fertilization when fertilized by older males. In breeding groups with older females and males, of 140 and 270 days of age, contrasts were not statistically significant, indicating that the age of males did not interfered with sptz/ $/ \mathrm{mm}^{2}$.

In males, reduced fertility is associated with the reduction in the number of sperm in the ejaculate and in the volume of semen produced (Lake, 1989). Moreover, roosters may present physical problems related to decreased libido, male-male competition, and physical injuries. Due to these characteristics, in broiler breeder farms the breeding management includes the partial replacement of old males by young males in the $40^{\text {th }}$ week, known as spiking (Bramwell et al., 1996). By examining couples of laying quails along their reproductive life, Santos et al. (2013) concluded that female age is the major cause of reduced fertility and the reduction occurs in both fertility and sptz/mm 2 as a function of the age of the breeders.

The possible causes for the decline in fertility of old hens include problems in the ability to store sperm in their reproductive tract or a decline in the ability to transport the sperm to the fertilization site. The same effect of female age on fertility is verified in broiler breeders. Old breeders have a significant reduction in fertility and sperm number trapped in fertile eggs (Bramwell et al., 1996). This effect is observed even in breeders inseminated with semen from young males (Gumulka \& Kapkowska, 2005).
Table 04 - Mean values ( \pm standard deviation) and contrasts of the number of sperm per $\mathrm{mm}^{2}\left(\mathrm{sptz} / \mathrm{mm}^{2}\right)$ in the perivitelline membrane on the germinal disc of fertile eggs in groups of breeder quails with different ages.

\begin{tabular}{lc}
\hline Age of breeders & Sptz/mm² \\
\hline Female85 Male85 & $6.72 \pm 0.72$ \\
\hline Female85 Male140 & $12.20 \pm 3.01$ \\
\hline Female85 Male270 & $11.04 \pm 3.06$ \\
\hline Female140 Male85 & $7.00 \pm 1.72$ \\
\hline Female140 Male140 & $8.94 \pm 0.55$ \\
\hline Female140 Male270 & $9.58 \pm 1.67$ \\
\hline Female270 Male85 & $10.44 \pm 0.70$ \\
\hline Female270 Male140 & $8.34 \pm 1.47$ \\
\hline Female270 Male270 & $9.90 \pm 1.97$ \\
\hline Tested contrasts & $\mathrm{p} \mathrm{value}$ \\
\hline Female85 Male85 vs. Female85 Male140 & 0.012 \\
\hline Female85 Male85 vs. Female85 Male270 & 0.035 \\
\hline Female85 vs. Female140 & 0.230 \\
\hline Female85 vs. Female270 & 0.740 \\
\hline Female140 Male85 vs. Female140 Male140 & 0.290 \\
\hline Female140 Male85 vs. Female140 Male270 & 0.170 \\
\hline Female270 Male85 vs. Female270 Male140 & 0.320 \\
\hline Female270 Male85 vs. Female270 Male 270 & 0.810 \\
\hline Female i Male i : i = age in days (85, 140, and 270).
\end{tabular}

Besides this, there are other factors, such as reduced sperm transport through the oviduct, as well as reduced ability of sperm to remain viable in these glands. Brillard (1993) argues that in broiler breeders the sperm release rate in these glands is two times higher in old females compared with young ones, which would result in a reduction in the quantity of sperm stored over time and a shortened fertility period in old birds. For quails, the fertility period comprises an average of 6-8 days, and these birds may lay fertile eggs for up to 11 days (Sittman \& Abplanalp, 1965); the fertility period is the time in which a bird can produce fertile eggs after mating with the male.

In relation to embryonic mortality, the age of quail breeders affected the percentage of late embryonic mortality, since the young birds (85 days) showed the lowest percentage $(p<0.05)$. The early and intermediate embryonic mortality were not affected ( $p>0.05$ ) by the age of birds (Table 2 ). The raise in embryonic mortality and reduced survival of chicks are common in the eggs of very old chicken (Novo et al., 1997).

Considering the live performance from one to 35 days of quails (Table 5), there was an effect female age $(p<0.05)$ on one-day-old-chick weight and on the feed intake of quails between 15-35 days and 1-35 days for quails originated from breeders in the peak of lay at 140 days. These results can also be because larger eggs have higher yolk weights and higher phospholipid and protein contents at the end 
Table $\mathbf{5}$ - Live performance of the progeny of quails from 1 to 35 days of age according to the age of quail breeders.

\begin{tabular}{|c|c|c|c|c|c|c|c|c|c|c|}
\hline & Female & & & Male & & & & ANOVA & & \\
\hline & 85 & 140 & 270 & 85 & 140 & 270 & $\mathrm{CV} \%$ & $\mathrm{Fe}$ & Ma & $\mathrm{Fe} \times \mathrm{Ma}$ \\
\hline \multicolumn{11}{|c|}{ Body weight (g) } \\
\hline 14 days & 68.73 & 68.01 & 69.25 & 69.93 & 68.50 & 67.41 & 6.87 & ns & ns & ns \\
\hline 35 days & 217.46 & 219.99 & 217.21 & 217.98 & 220.19 & 216.41 & 2.33 & ns & ns & ns \\
\hline \multicolumn{11}{|l|}{ Weight gain (g) } \\
\hline 1 to 14 days & 59.67 & 58.40 & 60.21 & 60.72 & 59.28 & 58.10 & 7.78 & ns & ns & ns \\
\hline 15 to 35 days & 148.72 & 151.98 & 147.96 & 148.50 & 151.69 & 149.00 & 3.63 & ns & ns & ns \\
\hline 1 to 35 days & 208.39 & 210.38 & 208.17 & 208.77 & 210.97 & 207.10 & 2.41 & ns & ns & ns \\
\hline \multicolumn{11}{|l|}{ Feed intake (g) } \\
\hline 1 to 14 days & 129.28 & 127.13 & 125.85 & 125.69 & 126.04 & 124.41 & 5.61 & ns & ns & ns \\
\hline 15 to 35 days & $392.17^{b}$ & $405.43^{a}$ & $400.12^{\mathrm{ab}}$ & 399.21 & 402.79 & 394.61 & 3.20 & $0.056^{*}$ & ns & ns \\
\hline 1 to 35 days & $515.45^{b}$ & $532.56^{a}$ & $525.96^{a b}$ & 525.54 & 528.83 & 519.01 & 2.89 & 0.035 & ns & ns \\
\hline \multicolumn{11}{|c|}{ Feed conversion ratio $(\mathrm{kg} / \mathrm{kg})$} \\
\hline 1 to 14 days & 2.08 & 2.18 & 2.09 & 2.08 & 2.12 & 2.14 & 6.23 & ns & ns & ns \\
\hline 15 to 35 days & 2.64 & 2.67 & 2.71 & 2.67 & 2.65 & 2.65 & 3.66 & ns & ns & ns \\
\hline 1 to 35 days & 2.45 & 2.51 & 2.49 & 2.48 & 2.49 & 2.47 & 2.67 & ns & ns & ns \\
\hline \multicolumn{11}{|c|}{ Daily weight gain (g) } \\
\hline 1 to 14 days & 4.26 & 4.17 & 4.30 & 4.34 & 4.23 & 4.15 & 7.77 & ns & ns & ns \\
\hline 1 to 35 days & 5.95 & 6.01 & 5.95 & 5.97 & 6.02 & 5.92 & 2.40 & ns & ns & ns \\
\hline Viability (\%) & 86.67 & 90.83 & 89.85 & 88.89 & 85.14 & 93.63 & 6.99 & ns & ns & ns \\
\hline
\end{tabular}

${ }^{a-b}$ means of the same variable followed by different letter in the same row differ significantly for the treatments by Tukey test $(p<0.05) ;{ }^{*} p$ value; ns: not significant ( $\left.p>0.05\right)$.

of the incubation period, when there is a transfer of nutrients from the yolk sac to the embryo, and result in larger chicks at hatch and better development of birds during the rearing period (Noble et al., 1986; Ding \& Lilburn, 1996). Analyzing Japanese quail breeders from 42 to 154 days, Yannakopoulos \& Tserveni-Gousi (1987) described a positive correlation between chick weight and egg weight. Breeders between 70 and 120 days laid larger eggs $(12.4 \mathrm{~g})$, with better hatchability $(72.2 \%)$ and larger chicks when compared to the other age groups analyzed.

Despite the initial difference in one-day-old-chick weight, this difference was not maintained over the rearing period, and after 14 days, there was no significant difference (Table 4). Corrêa et al. (2011) evaluated the effect of the interaction of breeder age (70, 205 and 280 days) with egg weight on the live performance of quails and verified that quails originated from heavier eggs and breeders with 205 and 280 days of age showed a better performance $(p<0.05)$. The authors reported that the greater body weight and weight gain at 21 days of age was achieved in quails from breeders of 205 and 280 days of age. When feed conversion ratio data were analyzed, no difference ( $p>0.05$ ) was found as function of breeders age, in agreement with Corrêa et al. (2011), in quails at 42 days of age.

With respect to live performance of the progeny of broiler breeders, Maiorka (2002) reported that chicks from older breeders have a more developed digestive tract at hatch. This feature could allow birds to improve the adaptation to exogenous feeding and feed utilization, as well as to perform better (Hudson et al., 2004). Proudfoot et al. (1982) worked with broiler breeders and also registered a better feed intake for chicks from larger eggs.

In conclusion, quail breeders with 140 days produced more eggs with heavier weights and heavier chicks, without losses in egg quality, breeding and incubation. Breeders with 270 days may retain their fertility and hatchability, but produce less and lighter eggs than younger breeders.

\section{ACKNOWLEDGEMENTS}

To the National Council for Scientific and Technological Development (CNPq) for financial support. 


\section{REFERENCES}

Akyurek $\mathrm{H}$, Okur AA. Effect of storage time, temperature and hen age on egg quality in free-range layer hens. Journal of Animal and Veterinary Advances 2009:8:1953-1958.

Albino LFT, Barreto SLT. Criação de codornas para produção de ovos e carne. Viçosa: Aprenda fácil; 2003. 289p.

Aya『an T. Effects of dietary inclusion of protexin (probiotic) on hatchability of Japanese quails. Indian Journal of Animal Science, 2013a;83(1):7881

Aya冈an T. Effects of dietary Yucca schidigera on hatchability of Japanese Quails. Indian Journal of Animal Science, 2013b; 83(6):641-644.

Bramwell RK, McDaniel CD, Wilson JL Howarth B. Age effect of male and female broiler breeders on sperm penetration of the perivitelline layer overlying the germinal disc. Poultry Science 1996;75:755-762.

Brillard J. Sperm storage and transport following natural mating and artificial insemination. Poultry Science 1993;72:923-928.

Clulow J, Jones RC. Production, transport, maturation, storage and survival of spermatozoa in the male Japanese quail Coturnix coturnix. Journal of Reproduction and Fertility 1982;64:259-266.

Corrêa AB, Silva MA, Corrêa GSS, Santos GG, Felipe S, Wenceslau RR, Souza GH, Campos NCFL. Efeito da interação idade da matriz x peso do ovo sobre o desempenho de codornas de corte. Arquivo Brasileiro de Medicina Veterinária e Zootecnia 2011;63:433-440.

Costa CHR, Barreto SLT, Filho RMW, Araujo MS, Umiji RT, Lima HJ. Avaliação do desempenho e da qualidade dos ovos de codornas de corte de dois grupos genéticos. Revista Brasileira de Zootecnia 2008; 37:1823-1828.

Dere S, Inal S, Caglayan T, Garip M, Tilki M. The effects of parent age, egg weight, storage length and temperature on fertility and hatchability of Japanese quail. Journal of Animal and Veterinary Advances 2009;8(7):1289-1291.

Ding ST, Lilburn MS. Characterization of changes in yolk sac and liver lipids during embryonic and early posthatch development of turkey poults. Poultry Science 1996; 75:478-483.

Froman D, Kirby JD, Proudman JA. Reprodução em aves: macho e fêmea. In: Hafez B, Hafez ESE. Reprodução animal. 7th ed. Barueri: Manole; 2004. p.237-257

Gumułka M, Kapkowska E. Age effect of broiler breeders on fertility and sperm penetration of the perivitelline layer of the ovum. Animal Reproduction Science 2005;90:135-148.

Hassan SM, Mady ME, Cartwright AL, Sabri HM, Mobarak MS. Effect of feeding time on the reproductive performance of Japanese quail (Coturnix coturnix japonica). Poultry Science 2003;82:1188-1192.

Haugh RR. The Haugh unit for measuring egg quality. United States Egg Poultry Magazine 1937;43:552-573.

Hudson B, Dozier lii WA, Wilson JL, Sander JE, Ward TL. Reproductive performance and immune status of caged broiler breeder hens provided diets supplemented with either inorganic or organic sources of zinc from hatching to 65 wk of age. Journal of Applied Poultry Research 2004;13:349-359.

Kosin II. The accuracy of the macroscopic method in identifying unincubated germ discs. Poultry Science 1945;24:281-295.

Lake E. Recent progress in poultry reproduction. World's Poultry Science Journal 1989;45:53-59.

Maiorka A. Efeito da idade da matriz e do agente trófico (glutamina) sobre o desenvolvimento da mucosa intestinal e atividade enzimática do pâncreas de pintos de corte na primeira semana [tese]. Jaboticabal (SP): Universidade Estadual Paulista; 2002. 100p.
Móri C, Garcia EA, Pavan AC, Piccini A, Pizzolante CC. Desempenho e rendimento de carcaça de quatro grupos genéticos de codornas para produção de carne. Revista Brasileira de Zootecnia 2005a; 34(3):870876.

Móri C, Garcia EA, Pavan AC, Piccini A, Scherer MR, Pizzolante CC. Desempenho e qualidade dos ovos de codornas de quatro grupos genéticos. Revista Brasileira de Zootecnia 2005b;34:864-869.

Murakami AE, Ariki J. Produção de codornas japonesas. Jaboticabal: FUNEP, 1998. p. 79

Noble RC, Lonsdale F, Connor K, Brown D. Changes in the lipid metabolism of the chick embryo with parental age. Poultry Science 1986;65:409416

Novo R, Gama LT, Soares MC. Effects of oviposition time, hen age and extra dietary calcium on egg characteristics and hatchability. Journal of Applied Poultry Research 1997; 6:335-343.

Nowaczewski S, Kontecka H, Rosiñski A, Koberling S, Koronowski P. Egg quality of Japanese quail depends on layer age and storage time. Folia Biologica 2010;58:201-207.

Proudfoot FG, Hulan HW, Mcrae KB. Effect old hatching egg size from semi-dwarf and normal maternal meat parent genotypes on the performance of broiler chickens. Poultry Science 1982; 61:655-660.

Rocha JSR, Lara LJC, Baião NC, Cançado S, Baião LEC, Silva TR. Efeito da classificação dos ovos sobre o rendimento de incubação e os pesos do pinto e do saco vitelino. Arquivo Brasileiro de Medicina Veterinária e Zootecnia 2008;60:979-986.

Roll FB, Cepero RC, Levrino GAM. Floor versus cage rearing: effects on production, egg quality and physical condition of laying hens housed in furnished cages. Ciência Rural 2009;39:1527-1532.

Roque L, Soares MC. Effects of eggshell quality and broiler breeder age on hatchability. Poultry Science 1994;73:1838-1845

Rostagno HS, Albino LF, Donzele JL, Gomes C, Oliveira RF, Lopes DC, Ferreira AS, Barreto SLT. Tabelas brasileiras para aves e suínos: composição de alimentos e exigências nutricionais. 2.ed. Viçosa: UFV; 2005. p.186

Santos JEC, Gomes FS, Borges GLFN, Silva L, Campos EJ, Fernandes EA, Guimaraes E. Efeito da linhagem e da idade das matrizes na perda de peso dos ovos e no peso embrionário durante a incubação artificial. Bioscience Journal 2009;25:163-169

Santos TC, Murakami AE, Fanhani JC, Oliveira CAL. Production and reproduction of egg- and meat-type quails reared in different group sizes. Brazilian Journal of Poultry Science 2011;13:01-06.

Santos TC, Murakami AE, Oliveira CAL, Giraldelli N. Sperm-egg interaction and fertility of Japanese breeder quails from ten- to sixty-one weeks. Poultry Science 2013;92:205-210.

Sas Institute. User's guide 8.0. Cary; 2000.

Seker I, Ekmen F, Bayraktar M, Kul S. The effects of parental age and mating ratio on egg weight, hatchability and chick weight in Japanese quail. Journal of Animal and Veterinary Advances 2004; 3:424-430.

Sittmann $\mathrm{K}$, Abplanalp $\mathrm{H}$. Duration and recovery of fertility in Japanese quail (Coturnix coturnix japonica). Brithish Poultry Science 1965;6:245250.

Wilson HR. Interrelationships of egg size, chick size, post hatching growth and hatchability. World's Poultry Science Journal 1991;47:5-20.

Wishart GJ. Quantitative aspects of sperm:egg interaction in chickens and turkeys. Animal Reproduction Science 1997:48:81-92.

Yannakopoulos AL, Tserveni-Gousi AS. Research note: Effect of breeder quail age and egg weight on chick weight. Poultry Science, Review 1987:66:1558-1560. 